\title{
https://doi.org/10.46813/2021-131-088 \\ "STRING" TYPE OF BARRIERLESS PLASMA CHEMICAL REACTOR FOR GENERATION OZONE FROM AIR
}

\author{
D.V. Kudin, L.M. Zavada, P.O. Opalev, O.V. Kotukov, V.F. Khmelevska \\ National Science Center “Kharkov Institute of Physics and Technology”, Kharkiv, Ukraine \\ E-mail: opalev@kipt.kharkov.ua
}

The efficiency of ozone generation for barrierless plasma chemical reactors with different cathode designs was compared. The characteristics of ozone generation for a plasma chemical reactor with a string-type cathode in comparison with the previously developed star-shaped cathode for different combinations of bias and pulsed components of voltage have been investigated. The special feature of the operation of a plasma-chemical reactor with a string cathode is revealed. There is consisting in the absence of dependence of the transition of the discharge combustion mode into the spark breakdown phase from the presence of a bias voltage.

PACS: 52.80.Hc, 52.90.+z,52.75.-d.

\section{INTRODUCTION}

The high efficiency of the using ozonation for bactericidal water treatment [1], control of biological contamination of grain [2, 3] and other bactericidal applications has long been known. Recently, due to the spread of a new strain of coronavirus, attention to mobile technologies of sterilization and disinfection has increased significantly.

The main chemical reagent of ozonation technology - ozone can be produced "in situ" in a plasma chemical reactor from air or oxygen. Due to the high oxidizing ability of ozone, this technology allows you to effectively disinfect water, surfaces and bulk substances [4].

But for the most common in ozone generation technologies use plasma chemical reactor with dielectric barriers have a big problem in the low service life if ordinary air is used as the working gas, as well as the impossibility of restoring the dielectric barrier after transition of discharge in spark mode. Barrierless plasma chemical reactors based on a combination of a star-shaped cathode and a cylindrical anode developed at NSC KIPT haven't the above-mentioned problems and are also highly mobile and reliable [5]. In addition, it was demonstrated that such plasma chemical reactors can be used not only in ozone generation systems, but also in systems for controlling the content of volatile hydrocarbon compounds in the air [6,7]. But the heavy weight of the electrode system and the cost of its manufacture significantly reduce the competitive advantages of this type of system. The barrierless plasma cathodic systems with star-shaped cathodes to long-term using (more than a year) require maintenance, which also negatively affects their commercial attractiveness.

A possible alternative to using a star-shaped cathode is to replace it with another type of barrierless cathode, such as one consisting of stretched thin strings. The paper compares the efficiency of using star-shaped and string structures of electrodes to generate ozone from the air at different air flow rates through the plasma chemical reactor and the values of bias voltage [8].

\section{EXPERIMENTAL SETUP}

To increase the competitiveness of barrierless plasma chemical systems, in contrast to pre-designed electrode systems with a cathode consisting of a large number of star-shaped electrodes, was design new type of barrierless plasma chemical reactor - string. Photos of the central part of the reactors are shown in Fig.1. The tubular cylindrical carbon anode (see shown in Fig. 1 next to the string electrode) is the same for both types of reactors.

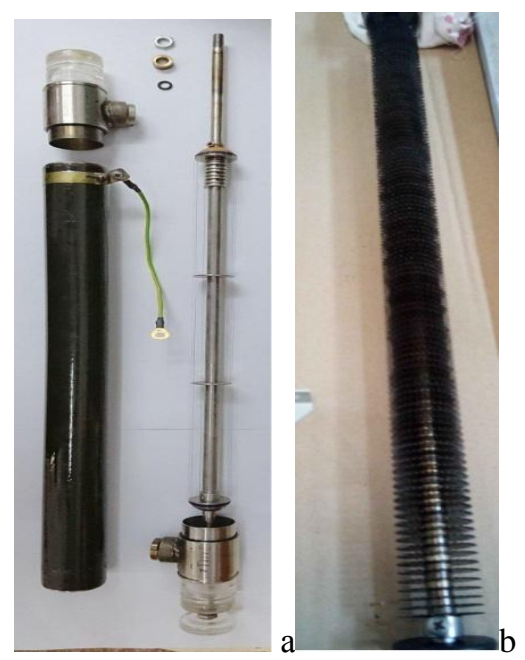

Fig. 1. Photos string (a) and star-shaped (b) electrods

The star-shaped cathode consisted of 100 "stars" with a diameter of $27 \mathrm{~mm}$ with 30 beams placed on a metal rod at a distance of $2.5 \mathrm{~mm}$. The weight was $3.6 \mathrm{~kg}$.

The string cathode consisted of 12 stretched by means of a special design pieces of metal wire with a thickness of $0.15 \mathrm{~mm}$. The weight was $2.7 \mathrm{~kg}$.

The advantages of the string cathode design are low weight and lower price.

To compare the efficiency of ozone generation, we used an experimental stand consisting of an air compressor SECOH, a switching power supply with variable systems for forming bias voltage, flow meters, 
power meter, ozone concentration meter Teledyne API Model 454 and oscilloscope. Photo stand shown in Fig. 2.

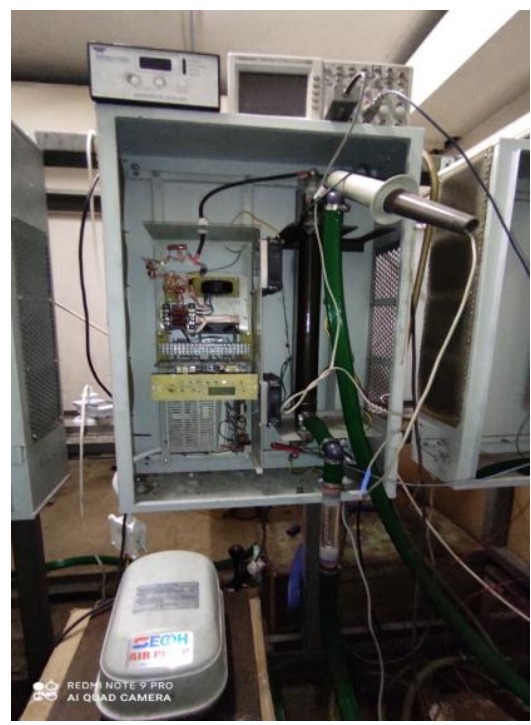

Fig. 2. Photo of experimental stand

The scheme of the experimental stand is shown in Fig. 3.

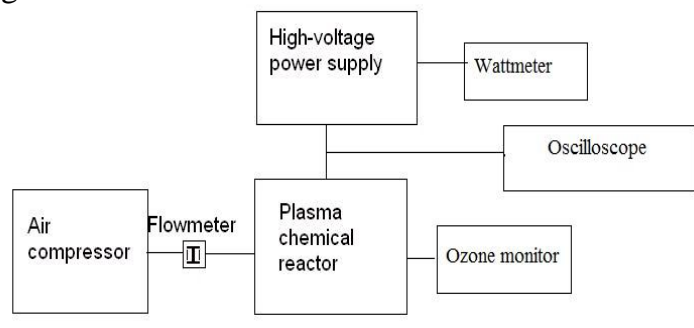

Fig. 3. Basic scheme of the experimental setup

High-voltage pulsed power supply forms highvoltage pulses of microsecond duration (1300 ns) with a pulse repetition rate of $1 . .15 \mathrm{kHz}$ and amplitude up to $15 \mathrm{kV}$. The rise time of the pulse is $500 \mathrm{~ns}$. The current pulse was recorded using a current shunt.

A characteristic oscillogram of the voltage pulse at complex power supply is shown in Fig. 4.

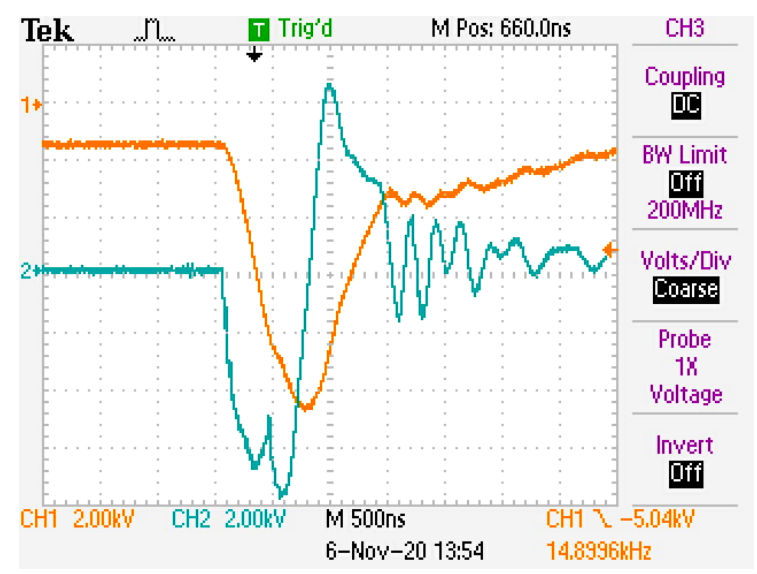

Fig. 4. The characteristic oscillogram of the supply voltage pulse of plasma chemical reactors

The supply voltage supplied to the plasma chemical reactor consists of DC (bias voltage) and pulse components. For this case, the pulse repetition frequency was $14.89 \mathrm{kHz}$, the bias voltage was $1.6 \mathrm{kV}$, and the total pulse amplitude was $11.4 \mathrm{kV}$. It should be noted that these parameters of the complex power supply of the reactor are optimal for long-term operation and efficiency of reactors with star-shaped cathodes [8].

The electric signals were recorded with a Tektronix TDS-2024 digital oscilloscope, bandwidth of $100 \mathrm{MHz}$.

Measurements of ozone concentration in the air were performed with a ozone concentration meter Teledyme API Model 454 with an accuracy of $0.1 \mathrm{~g} / \mathrm{m}^{3}$.

\section{RESULTS}

Energy consumption for the generation of grams of ozone is determined by the formula:

$$
w=\frac{P t}{c f}
$$

where $\mathrm{w}$ - specific energy consumption, P - energy consumed $\mathrm{W}, \mathrm{t}$ - time, $\mathrm{c}$ - ozone concentration, $\mathrm{f}$ - air flow through the plasma chemical reactor.

String and star-shaped reactors were tested to compare the efficiency of ozone generation at different air flows through a plasma chemical reactor at the same power, which is applied in the discharge $(104 \mathrm{~W})$ and the same power parameters (bias voltage $-1600 \mathrm{~V}$ ).

The test results are shown in Fig. 5.

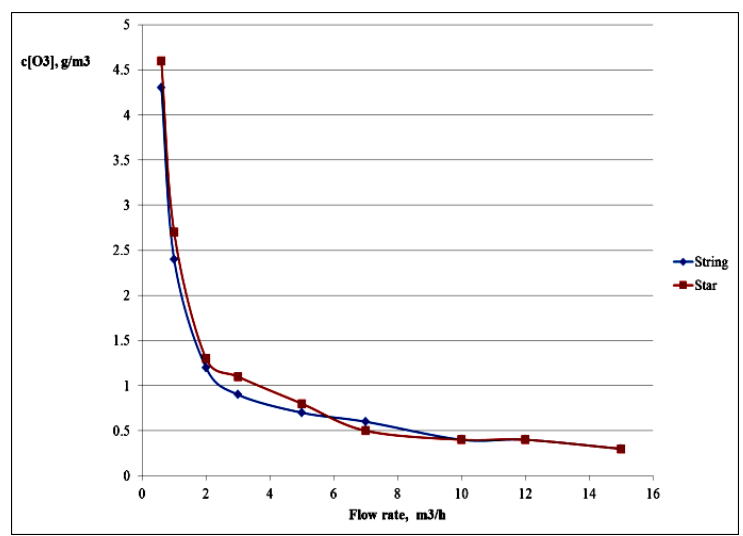

Fig. 5. The dependence of ozone concentration on air flow through a plasma chemical reactor for power applied in the discharge of $104 \mathrm{~W}$

It is seen that for this case the efficiency of ozone generation, i.e. energy consumption for ozone generation doesn't differ significantly.

It should be noted that the applied power at the level of $104 \mathrm{~W}$ is the maximum for the cathode of the string type without the transition of the mode of the discharge in the mode of spark breakdown. The maximum power that can be applied in a reactor with star-shaped cathodes is $126 \mathrm{~W}$.

For a string reactor the ignition voltage of discharge decreases by $1 \mathrm{kV}$ with increasing bias voltage from 0 to $1600 \mathrm{~V}$, and for a star-shaped electrode the ignition voltage gradually decreases by $2 \mathrm{kV}$ with increasing bias voltage from 0 to $1000 \mathrm{~V}$, and then increases sharply at $1.5 \mathrm{kV}$ with a bias voltage at the level of 
$1600 \mathrm{~V}$ for which the most stable long-term operation and maximum productivity are recorded.

It should be noted that the applied power in the discharge at the level of $104 \mathrm{~W}$ for a reactor with a starshaped cathode can be achieved only by using a complex voltage of power supply with a bias voltage, without a bias voltage, the maximum power that can be applied in the reactor the phase of the spark breakdown with a star-shaped electrode doesn't exceed $90 \mathrm{~W}$.

In Fig. 6 the graph of ozone concentration dependence for string and star-shaped cathodes depending on the value of the bias voltage of power supply voltage in the range $0 . .2000 \mathrm{~V}$ (for air flow through the reactor $1.6 \mathrm{~m}^{3} / \mathrm{h}$ ) is given.

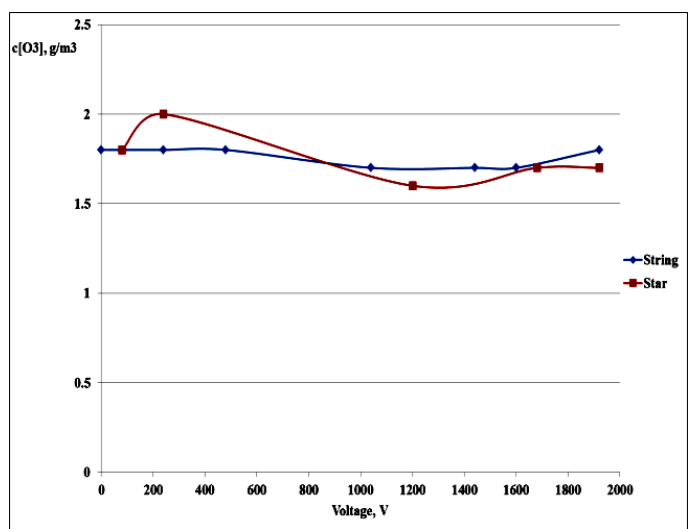

Fig. 6. Dependence of ozone concentration on the bias voltage at the same power, which is applied in the discharge and air flow through the plasma chemical reactor at the level of $1.6 \mathrm{~m}^{3} / \mathrm{h}$

It is seen that the ozone concentration for the string cathode (blue curve) differs at the level of measurement error, and for the star-shaped has a significant correlation with the value of bias voltage [8]. In Fig. 7 shows the dependence of the ozone concentration for the string cathode on the air flow through the plasma chemical reactor for the bias voltage at the level of 0 and $1600 \mathrm{~V}$ and the star-shaped reactor with a bias voltage of $1600 \mathrm{~V}$.

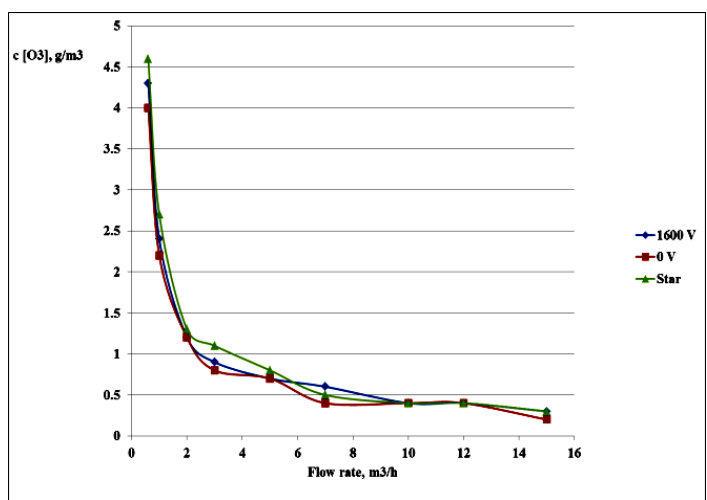

Fig. 7. Dependence of ozone concentration on air flow through a plasma chemical reactor

It is seen that the concentration of ozone doesn't differ significantly for different flow rate with a bias voltage and without.

Thus, for a plasma reactor of string type, there is no effect on the efficiency of ozone generation of the bias voltage, which has a significant effect on the stability and efficiency of ozone generation for reactors with a star-shaped cathode. The efficiency of ozone generation for both types of electrodes in a wide range of air flow through the plasma chemical reactor differs at a level less than the measurement error. The physical preconditions for the difference in the influence of the bias voltage should be studied in more detail, but it can be assumed that they are related to the difference in the formation of the bulk charge region for different electrode geometries.

\section{CONCLUSIONS}

A new design of a barrierless plasma chemical reactor for ozone generation was developed, manufactured and tested. Studies have shown a slight difference in the efficiency of ozone generation for both types of reactors. The string modification of the central cathode turned out to be $50 \%$ lighter and cheaper to manufacture compared to the star-shaped cathode and looks like a promising way to further upgrade the barrierless ozonators.

Also, the absence dependence of the transition to the discharge mode to the phase of spark breakdown from the value of bias voltage for string cathode is fixed.

\section{REFERENCES}

1. O.V. Mosin. The use of ozone in water treatment // Plumbing heating, air conditioning. 2011, № 9(117), p. 40-43. 2. G.V. Taran, V.A. Breslavets, A.A. Zamuriev, M.O. Yaroshenko, P.O. Opalev, O.V. Maiboroda. Plasma-chemical methods for control of biotic contaminants // Problems of Atomic Sci. and Technol. Series «Plasma Electronics and New Methods of Acceleration» (122). 2019, № 4, p. 198-202.

3. V.I. Golota, G.V. Taran, A.A. Zamuriev, P.O. Opalev, S.G. Pugach, S.M. Mankovskiy, V.P. Petrenkova, I.N. Nyska. The use of ozone technologies in grain storage // Problems of Atomic Science and Technology. Series «Plasma Electronics and New Methods of Acceleration» (116). 2018, № 4, p. 185-188.

4. R.V. Ponomarenko. Increasing the level of environmental safety of drinking water supply in the region in terms of surface source pollution // Ecological Safety. 2013, № 1(15), p. 24-27.

5. Patent US № 6,544,486 B2 Date 04/18/2003 V. Golota, O. Yegorov, V. Mykhaylov, V. Mukhin, G. Taran, S. Shilo.

6. V.I. Golota, L.M. Zavada, O.V. Kotyukov, D.V. Kudin, A.S. Pismenetskii, Y.V. Dotsenko. Methanol and ethanol vapour conversion in gas discharge with strongly non-uniform distribution of electric field on atmospheric pressure // Problems of Atomic Science and Technology. Series «Plasma Electronics and New Methods of Acceleration». 2010, № 4, p. 199-203.

7. V.I. Golota, L.M. Zavada, O.V. Kotukov, D.V. Kudin, S.V. Rodionov, A.S. Pismenetskii, Y.V. Dotsenko. Decomposition of dichloroethane vapor in barrierless discharge // Problems of Atomic Science and Technology. Series «Plasma Physics». 2010, № 6, p. $182-184$. 
8. S.M. Mankovskyi, B.B. Kadolin, L.M. Zavada, V.I. Golota, M.O. Yegorov. Features of the microsecond pulsed discharge ignition in oxygen in a point-to-plane configuration // Problems of Atomic
Science and Technology. Series «Plasma Electronics and New Methods of Acceleration». 2018, № 4(116), p. 168-171.

Article received 05.01.2021

\title{
БЕЗБАРЬЕРНЫЙ РЕАКТОР «СТРУННОГО» ТИПА ДЛЯ ГЕНЕРАЦИИ ОЗОНА ИЗ ВОЗДУХА
}

\author{
Д.В. Кудин, Л.М. Завада, П.О. Опалев, О.В. Котюков, В.Ф. Хмелевская
}

Проведено сравнение эффективности наработки озона для безбарьерных плазмохимических реакторов с различными конструкциями катодов. Исследованы особенности генерации озона для плазмохимического реактора с катодом «струнного» типа по сравнению с разработанным ранее звездообразным катодом для различных комбинаций постоянных и импульсных составляющих питания. Выявлена особенность работы плазмохимического реактора со струнным катодом, которая заключается в отсутствии зависимости перехода режима горения разряда в фазу искрового пробоя от наличия постоянной составляющей комплексного питания.

\section{БЕЗБАР’ЄРНИЙ РЕАКТОР «СТРУННОГО» ТИПУ ДЛЯ ГЕНЕРАЦЇ ОЗОНУ 3 ПОВІТРЯ}

Д.В. Кудін, Л.М. Завада, П.О. Опалев, О.В. Котюков, В.Ф. Хмелівська

Проведено порівняння ефективності напрацювання озону для безбар'єрних плазмохімічних реакторів 3 різними конструкціями катодів. Досліджено особливості генерації озону для плазмохімічного реактора 3 катодом «струнного» типу порівняно з розробленим раніше зіркоподібним катодом для різних комбінацій постійних та імпульсних складових живлення. Виявлена особливість роботи плазмохімічного реактора зі струнним катодом, що полягає у відсутності залежності переходу режиму горіння розряду у фазу іскрового пробою від наявності постійної складової комплексного живлення. 